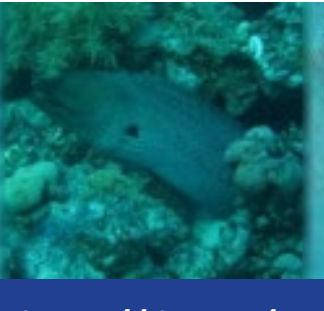

AQUATIC RESEARCH

E-ISSN 2618-6365

\title{
TRACE TOXIC MINERAL LEVELS OF SEA LETTUCE (Ulva spp.) FROM COAST OF ISTANBUL
}

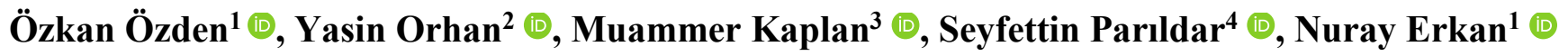

\author{
Cite this article as: \\ Özden, Ö., Orhan, Y., Kaplan, M., Parıldar, S., Erkan, N. (2019). Trace toxic mineral levels of sea lettuce (Ulva spp.) from coast of Istanbul. Aquatic \\ Research, 2(3), 154-160. https://doi.org/10.3153/AR19013
}

\footnotetext{
${ }^{1}$ Istanbul University, Faculty of Aquatic Sciences, Department of Fisheries and Seafood Processing Technology, Fatih, 34134, Istanbul, Turkey

2 Istanbul University, Institute of Graduate Studies in Science, Esnaf Hastanesi Binası 4. Kat Süleymaniye/İstanbul

3 TÜBITTAK Marmara Research Center, Food Institute, Gebze, 41470, Kocaeli,

${ }^{4}$ Uzman Gida Kontrol Laboratuvarı, Beşiktaş, 34347, Istanbul, Turkey
}

ORCID IDs of the author(s):

Ö.Ö. 0000-0001-8780-480X

Y.O. 0000-0001-7959-577X

M.K. 0000-0002-8312-5479

S.P. 0000-0002-1604-2614

N.E. 0000-0002-0752-8495

Submitted: 19.03.2019

Revision requested: 23.04 .2019

Last revision received: 06.05 .2019

Accepted: 06.05.2019

Published online: 08.07.2019

Correspondence:

Yasin ORHAN

E-mail: orhanjasin@yahoo.com

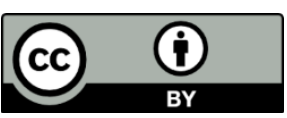

CCopyright 2019 by ScientificWebJournals Available online at

$\underline{\text { http://aquatres.scientificwebjournals.com }}$

\begin{abstract}
Concentrations of Nickel (Ni), Copper (Cu), Zinc (Zn), Iron (Fe), Arsenic (As), Mercury (Hg), Lead $(\mathrm{Pb})$ and Cadmium $(\mathrm{Cd})$ were determined in the macro algae sea lettuce (Ulva spp.), sampled from the coastline of Istanbul old city (Cankurtaran) in summer 2016. The abundance of trace toxic mineral concentrations in sea lettuce were in the following order: $\mathrm{Fe}>\mathrm{Zn}>\mathrm{As}>\mathrm{Cu}>\mathrm{Ni}>\mathrm{Pb}>$ $\mathrm{Cd}$. However, mercury was not detected in any sample. The present study provides a new information to the consumer on the distribution of trace toxic minerals in sea lettuce.
\end{abstract}

Keywords: Marmara Sea, Istanbul coast, Trace toxic minerals, Ulva spp., Sea lettuce 


\section{Introduction}

Trace toxic minerals are natural substances that have a high atomic weight and a density at least 5 times greater than that of water and these minerals are termed as heavy metals. Some trace minerals taken together with the food have a very important role in human life and are known to be necessary up to a certain concentration for human metabolism, as in the example iron, zinc and copper. Whereas, the majorities of heavy metals are toxic even at low concentrations such as arsenic, cadmium, chromium, lead and mercury. The multiple factors such as industrial, agricultural, medical and technological applications of trace toxic minerals have led their wide distribution in the environment. The trace toxic minerals, in particular, mercury, lead, cadmium and arsenic are frequently detected in aquatic organisms and raised concerns regarding the potential human health impacts. The toxic effects of these trace minerals may depend upon a variety of factors such as dose, exposure route and chemical structure, as well as age, gender, genetics and nutritional status of the exposed individuals (Belitz et al., 2009; Özcan, 2004; Soylak et al., 2005; Tchounwou et al., 2012).

The degree of pollution by trace toxic minerals in marine environments can be estimated by analysis of water, sediment and tissues of organisms (Morillo et al., 2005). Marine algae species are generally used to determine coastal waters trace toxic mineral grades in worldwide. In this process, it takes advantage of the key role of algae in the food chain and its temporal relationship with the pollutants (Topcuoğlu et al.,
2010). The analysis of sediments in marine environments always faces limitations and the concentration of a trace toxic mineral in the sediment varies, among other factors, depending on the rate of deposition and the nature of the particles. This does not reflect the bioavailability. Macro algae appear to be the most appropriate indicators of both active and passive minerals (Villares et al., 2010). Sea lettuce (Ulva lactuca) is a macro algae which has the potential importance in terms of bio indicators with the tendency to absorb trace toxic minerals and spread in cytoplasmic cells in marine contamination with toxic pollutants (Davis et al., 2003).

Trace toxic mineral-related pollution in coastal regions of Marmara Sea has become a significant problem because of intensive industrial activity, ship wastes, dense population and construction origin pollution and municipality wastewater discharges. Sea lettuce is a type of macro algae and continues its vital activities by fixing itself to rocks and taking nourishment from marine environment. Figure 1 shows the general distributions of this species, which has a large habitat from tropical to polar areas. This species is frequently seen in the rocky coastal lanes of the Black Sea, Marmara and Aegean Sea in Turkey.

Therefore, the aim of the present study is to evaluate the pollution in the Marmara Sea through determination of trace toxic metals in the sea lettuce obtained from old city region Cankurtaran Istanbul coast of the Marmara Sea.

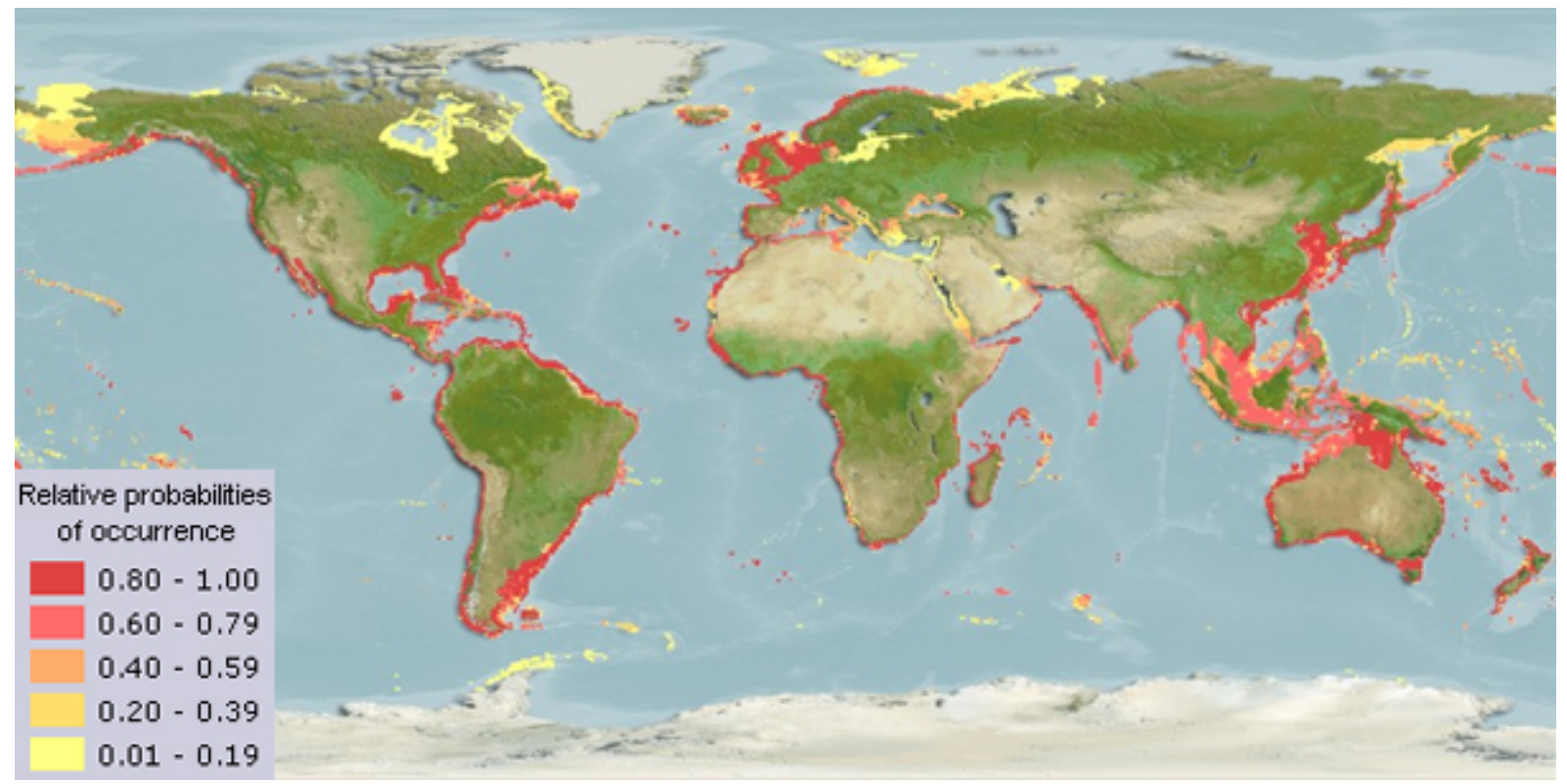

Figure 1. The habitats and distribution (native range) of Ulva lactuca in world (AquaMaps, 2016a) 


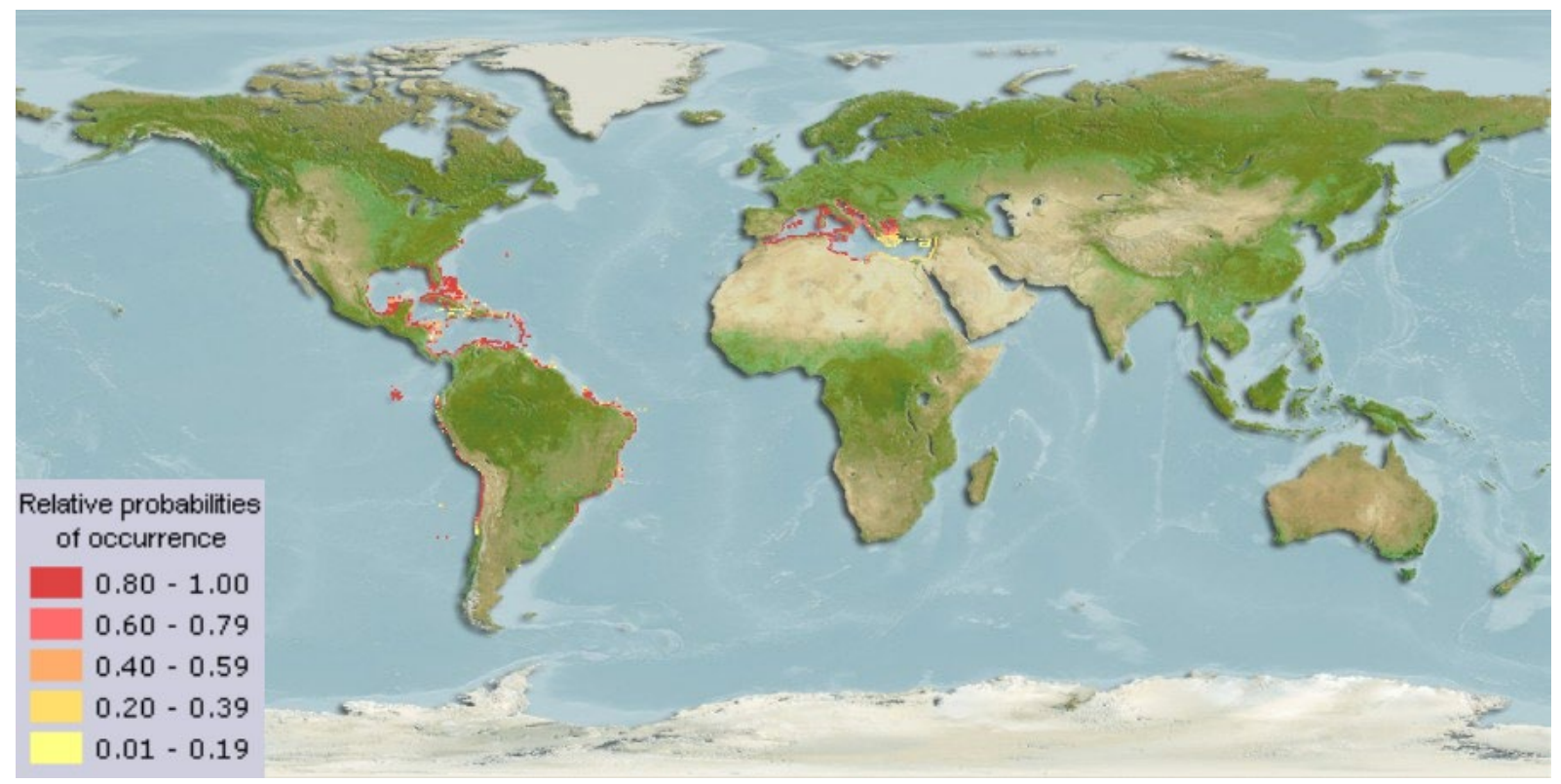

Figure 1. The habitats and distribution (native range) of Ulva rigida in world (AquaMaps, 2016b)

\section{Material and Methods}

Sea lettuce (Ulva spp.) were obtained (5 kg wet sample) from old city region Cankurtaran, Istanbul coast of the Marmara Sea (Figure 1) in year 2016 (end of summer) and dried under shadow (end dry product $\sim 1 \mathrm{~kg}$ ).

Determination of trace toxic minerals in dry sea lettuce $(\mathrm{Ni}$, $\mathrm{Cu}, \mathrm{Zn}, \mathrm{Fe}, \mathrm{As}, \mathrm{Hg}, \mathrm{Pb}, \mathrm{Cd}$ ) was carried out using an Inductively Coupled Plasma - Mass Spectrometry (ICP-MS) (Analytic Jena PlasmaQuant ${ }^{\circledR}$ MS, ICP-MS). An aliquot of 250 mg dried sea lettuce sample was weight into a pre-cleaned Teflon tube and $8 \mathrm{~mL}$ of concentrated nitric acid (65\%) added. The samples digested by microwave assisted digestion system. (Table 1.). After digestion, samples diluted to $50 \mathrm{~mL}$ with ultrapure water. The analysis performed with "NMKL No: 186 - Trace Elements - As, Cd, Hg, Pb and Other minerals. Determination by ICP-MS After Pressure Digestion, 2007" method (NMKL "Nordic Committee On Food Analysis", 2007) (Table 2., 3.). The accuracy and precision of the analytical method checked using the certified reference material, powdered muscle tissue (Catalogue No. ERMBB422). It was found that RSD \% did not exceed 5.0\%. All trace toxic mineral concentrations were determined on a $\mathrm{mg} / \mathrm{kg}$ dry weight basis.

Table 1. Microwave Digestion program for sea lettuce sample preparation

\begin{tabular}{ccccc}
\hline \multicolumn{5}{c}{ Berghof Microwave Unit (Berghof - Speedwave SW4) } \\
\hline $\begin{array}{c}\text { Temperature } \\
\left({ }^{\circ} \mathbf{C}\right)\end{array}$ & $\begin{array}{c}\text { Pressure } \\
(\mathbf{b a r})\end{array}$ & $\begin{array}{c}\text { Ramp } \\
(\mathbf{m i n})\end{array}$ & $\begin{array}{c}\text { Time } \\
(\mathbf{m i n})\end{array}$ & Power (\%) \\
\hline 155 & 50 & 8 & 8 & 90 \\
\hline 205 & 50 & 8 & 30 & 90 \\
\hline 50 & 0 & 1 & 15 & 0 \\
\hline
\end{tabular}




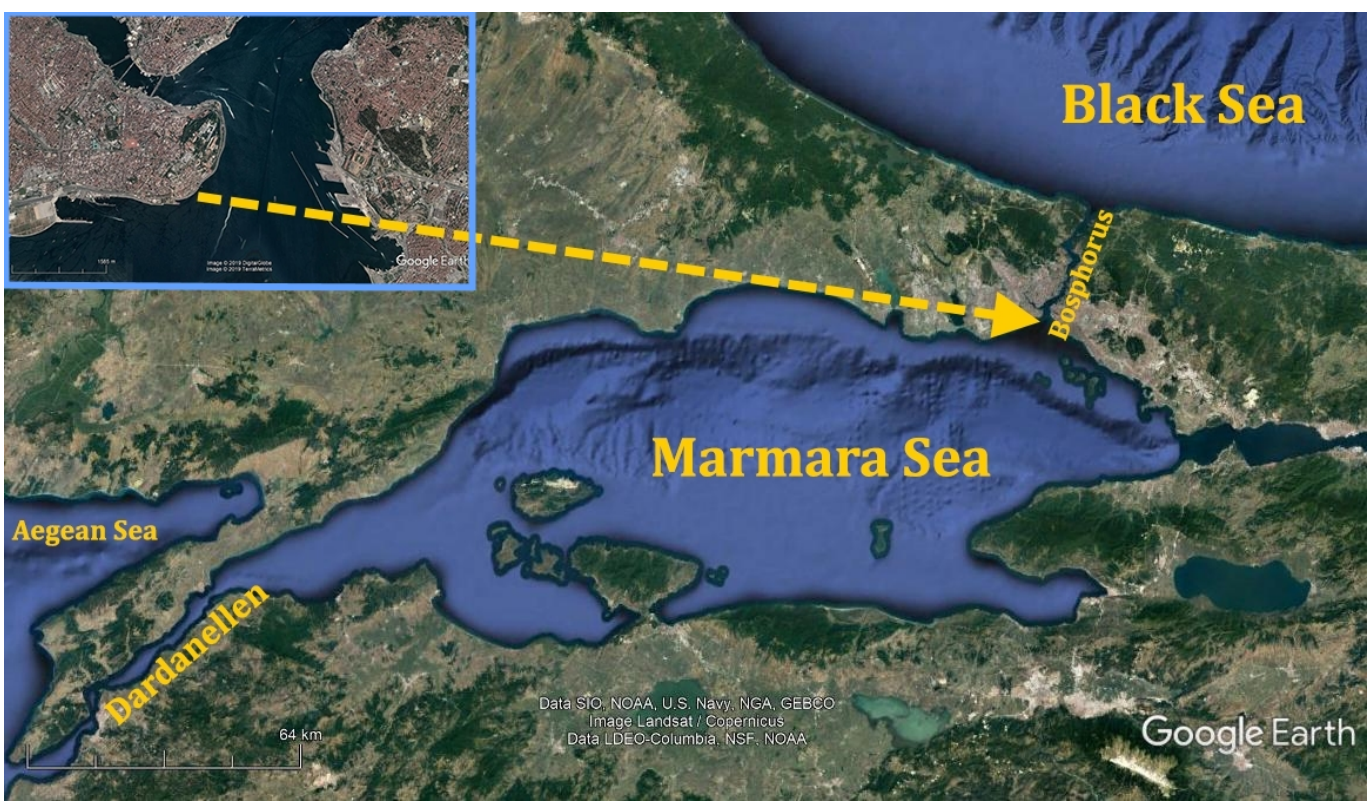

Figure 1: Istanbul old city coast (Cankurtaran) of Marmara Sea.

Table 2. ICP-MS operating parameters for the quantification of trace toxic minerals in sea lettuce

\begin{tabular}{cc}
\hline $\begin{array}{c}\text { ICP-MS (Analytic JENA Plasma } \\
\text { Quant MS Elite) application pa- } \\
\text { rameters }\end{array}$ & Parameters Used \\
\hline Nebulizer Gas Flow & $1.06 \mathrm{~L} / \mathrm{min}$. \\
\hline Auxiliary Gas Flow & $1.3 \mathrm{~L} / \mathrm{min}$. \\
\hline Plasma Gas Flow & $9.0 \mathrm{~L} / \mathrm{min}$. \\
\hline ICP RF Power & $1400 \mathrm{watts}$ \\
\hline Pump Rate & $10 \mathrm{rpm}$ \\
\hline Stabilization Delay & $40 \mathrm{~second}$ \\
\hline
\end{tabular}

Table 2. Trace toxic mineral standards used to establish ICP-MS calibration curve

\begin{tabular}{cccccc}
\hline \multicolumn{7}{c}{$\begin{array}{c}\text { Specifications of Standards used in ICP-MS } \\
\text { Name }\end{array}$} & Trademark & $\begin{array}{c}\text { Catalogue } \\
\text { Number }\end{array}$ & $\begin{array}{c}\text { Main Stock } \\
\text { Concentration }\end{array}$ & $\begin{array}{c}\text { Measured in ICP- } \\
\text { MS mass value }\end{array}$ & $\begin{array}{c}\text { LOQ } \\
\text { (ng/mL) }\end{array}$ \\
\hline $\mathbf{N i}$ & VHG & PNIN-100 & $999 \mu \mathrm{g} / \mathrm{mL}$ & 60 & 125.36 \\
\hline $\mathbf{C u}$ & VHG & ACUN-100 & $1001 \mu \mathrm{g} / \mathrm{mL}$ & 65 & 76.77 \\
\hline $\mathbf{Z n}$ & VHG & PZNN-100 & $1000 \mu \mathrm{g} / \mathrm{mL}$ & 66 & 428.05 \\
\hline $\mathbf{F e}$ & VHG & PFEN-100 & $1000 \mu \mathrm{g} / \mathrm{mL}$ & 56 & 601.42 \\
\hline $\mathbf{A s}$ & VHG & PASN-100 & $1008 \mu \mathrm{g} / \mathrm{mL}$ & 75 & 105.04 \\
\hline $\mathbf{H g}$ & VHG & PHGN-100 & $1002 \mu \mathrm{g} / \mathrm{mL}$ & 200 & 44.57 \\
\hline $\mathbf{P b}$ & VHG & PPBN-100 & $1005 \mu \mathrm{g} / \mathrm{mL}$ & 206 & 31.50 \\
\hline $\mathbf{C d}$ & VHG & PCDN-100 & $1000 \mu \mathrm{g} / \mathrm{mL}$ & 111 & 18.53 \\
\hline $\mathbf{Y}$ & Inorganic Ventures & GGY1-1 & $1001 \mu \mathrm{g} / \mathrm{mL}$ & 89 & - \\
\hline
\end{tabular}

Y (Ittrium) element is used as internal standard in the device 


\section{The internal standard concentration used was $2.0 \mathrm{ng} / \mathrm{mL}$}

Table 3. Concentration levels of the standards for ICP-MS Calibration curve

\begin{tabular}{|c|c|c|c|c|c|c|c|}
\hline \multirow{2}{*}{$\begin{array}{l}\text { Element } \\
\text { Name }\end{array}$} & \multicolumn{6}{|c|}{ Calibration Points of the Elements } & \\
\hline & Level 1 & Level 2 & Level 3 & Level 4 & Level 5 & $\begin{array}{c}\text { Level } \\
6\end{array}$ & \\
\hline $\mathbf{N i}$ & 0.5 & 2.5 & 5 & 10 & 20 & 50 & \multirow{8}{*}{$\mathbf{n g} / \mathbf{m L}$} \\
\hline $\mathbf{C u}$ & 0.3 & 2.5 & 5 & 10 & 50 & 100 & \\
\hline $\mathbf{Z n}$ & 2 & 10 & 50 & 100 & 250 & 500 & \\
\hline $\mathbf{F e}$ & 2.5 & 10 & 20 & 50 & 100 & 250 & \\
\hline As & 0.5 & 1 & 2,5 & 5 & 10 & 50 & \\
\hline Hg & 0.2 & 0.5 & 1 & 2.5 & 5 & 10 & \\
\hline $\mathbf{P b}$ & 0.15 & 0.5 & 1 & 2.5 & 5 & 10 & \\
\hline $\mathbf{C d}$ & 0.08 & 0.3 & 1 & 2.5 & 5 & 10 & \\
\hline
\end{tabular}

\section{Results and Discussion}

The present study provides new information on the distribution of trace toxic minerals in sea lettuce (Ulva spp.) obtained from Cankurtaran, the old city coast of Istanbul (European seaside). The trace toxic mineral concentrations determined in the algae samples studied are given in Table 1.

The present study reports the trace toxic minerals pollution in the samples collected from the Istanbul old city (Cankurtaran) coastline in the summer of 2016. Similarly, in 2014, Ozyigit et al. studied trace toxic mineral contents of sea lettuce samples collected from different parts of Istanbul including Istanbul old city coast (Cankurtaran) station, Büyükada, Fenerbahçe, Maltepe, Bakırköy and Beylikdüzü stations (Ozyigit et. al., 2017). Table 5, shows the trace toxic mineral contents of sea lettuce samples collected from different coastal cities of Marmara Sea. The results of their study is presented in Table 5. As can be seen from the Table, the sea lettuce samples collected from Cankurtaran coastline were found to contain much lower levels of $\mathrm{Cu}, \mathrm{Zn}, \mathrm{Fe}, \mathrm{Pb}$ and $\mathrm{Cd}$ than other coastal cities of Istanbul including Büyükada, Fenerbahçe, Maltepe, Bakırköy and Beylikdüzü. Consequently, it can be concluded that the Istanbul old city (Cankurtaran) coast is less affected from trace toxic mineral pollution than its other cities with coasts to Marmara Sea.
Trace toxic mineral contents of sea lettuce collected from other cities with coasts to Marmara Sea were also reported in the literature (Table 5 and Table 6).

Culha et al. studied the trace toxic mineral contents of sea lettuce samples collected from city of Yalova located on the coast of Marmara Sea (Culha et al., 2013). They reported lower $\mathrm{Cd}, \mathrm{Zn}, \mathrm{Ni}$ and $\mathrm{Pb}$ contents compared to our results for the sea lettuce samples obtained from Cankurtaran, coast of Istanbul old city (Table 6). However, $\mathrm{Cu}$ and $\mathrm{Fe}$ levels of sea lettuce collected from Cankurtaran were much lower than the samples collected from Yalova. In the same study, no information is reported for As and $\mathrm{Hg}$ in the samples of Yalova region.

In another study, Ergul et al. determined the trace toxic mineral contents of sea lettuce collected from Dilovası coast shore of Izmit Bay in 2009 (Ergul et al., 2010). The amounts of trace toxic minerals contained in the sea lettuce samples collected during the summer and autumn of 2009 were much higher (Zn:125.95-373.1 mg/kg, Fe: $1518.9-5249.8 \mathrm{mg} / \mathrm{kg}$ and $\mathrm{Pb}: 1.05-1.95 \mathrm{mg} / \mathrm{kg}$ ) than the samples collected from old city coast of Istanbul (Cankurtaran) during the Summer of 2016 (Table 6). 
Table 4. Toxic elements determined in Ulva spp. samples

\begin{tabular}{lcccccccc}
\hline Toxic Lements (mg/kg) & $\mathbf{N i}$ & $\mathbf{C u}$ & $\mathbf{Z n}$ & $\mathbf{F e}$ & $\mathbf{A s}$ & $\mathbf{H g}$ & $\mathbf{P b}$ & $\mathbf{C d}$ \\
\hline Sea lettuce & 1.32 & 4.92 & 6.92 & 88.74 & 3.65 & n.d. & 0.26 & 0.05 \\
& \pm 0.04 & \pm 0.10 & \pm 0.25 & \pm 3.57 & \pm 0.11 & & \pm 0.01 & \pm 0.00 \\
\hline
\end{tabular}

n.d. Not Detected $<0.02 \mathrm{ng} / \mathrm{kg}$

Table 5. Trace toxic mineral contents $(\mathrm{mg} / \mathrm{kg})$ of the sea lettuce samples obtained from present study and those reported by Özyiğit et al. (2017) and Culha et al. (2013)

\begin{tabular}{ccccccc}
\hline Sea lettuce & Büyükada & Fenerbahçe & Maltepe & Bakırköy & Beylikdüzü & $\begin{array}{c}\text { Istanbul old city coast } \\
\text { (Cankurtaran) }^{\mathbf{a}}\end{array}$ \\
\hline $\mathbf{C d}$ & $0.45 \pm 0.01$ & $1.01 \pm 0.01$ & $1.49 \pm 0.03$ & $2.22 \pm 0.04$ & $3.22 \pm 0.05$ & $\mathbf{0 . 0 5} \pm 0.00$ \\
\hline $\mathbf{C u}$ & $6.67 \pm 0.10$ & $10.92 \pm 0.13$ & $13.01 \pm 0.15$ & $15.28 \pm 0.17$ & $18.31 \pm 0.20$ & $\mathbf{4 . 9 2} \pm 0.10$ \\
\hline $\mathbf{F e}$ & $553.3 \pm 11.00$ & $686.2 \pm 13.10$ & $721.23 \pm 16.12$ & $775.3 \pm 19.20$ & $989.3 \pm 29.20$ & $\mathbf{8 8 . 7 4} \pm 3.57$ \\
\hline $\mathbf{P b}$ & $4.93 \pm 0.07$ & $7.63 \pm 0.09$ & $8.92 \pm 0.10$ & $12.35 \pm 0.20$ & $19.32 \pm 0.25$ & $\mathbf{0 . 2 6} \pm 0.01$ \\
\hline $\mathbf{Z n}$ & $15.16 \pm 0.22$ & $22.23 \pm 0.52$ & $26.87 \pm 0.73$ & $31.88 \pm 0.81$ & $41.23 \pm 1.02$ & $\mathbf{6 . 9 2} \pm 0.25$ \\
\hline $\mathbf{N i}$ & No Data & No Data & No Data & No Data & No Data & $\mathbf{1 . 3 2} \pm 0.04$ \\
\hline $\mathbf{A s}$ & No Data & No Data & No Data & No Data & No Data & $\mathbf{3 . 6 5} \pm 0.11$ \\
\hline $\mathbf{H g}$ & No Data & No Data & No Data & No Data & No Data & n.d \\
\hline
\end{tabular}

n.d. Not Detected $<0.02 \mathrm{ng} / \mathrm{kg}$

Table 6. Comparison of the results $(\mathrm{mg} / \mathrm{kg}$ ) obtained from the present study and the data reported in the literature.

\begin{tabular}{ccccc}
\hline $\begin{array}{c}\text { Sea } \\
\text { lettuce }\end{array}$ & $\begin{array}{c}\text { Istanbul old city coast } \\
\text { (Cankurtaran) }^{\mathbf{a}}\end{array}$ & $\begin{array}{c}\text { Yalova } \\
\text { (Culha et al., 2009) }^{\text {(C) }}\end{array}$ & \multicolumn{2}{c}{$\begin{array}{c}\text { Dilovasi/Kocaeli } \\
\text { (Ergul et al., 2010) } \\
\text { Summer } / \text { Autumn }\end{array}$} \\
\hline $\mathbf{C d}$ & $\mathbf{0 . 0 5} \pm 0.00$ & $<0.01$ & No Data & No Data \\
\hline $\mathbf{C u}$ & $\mathbf{4 . 9 2} \pm 0.10$ & 12.44 & No Data & No Data \\
\hline $\mathbf{F e}$ & $\mathbf{8 8 . 7 4} \pm 3.57$ & 358.36 & 1518.9 & 5249.8 \\
\hline $\mathbf{P b}$ & $\mathbf{0 . 2 6} \pm 0.01$ & $<0,01$ & 1.05 & 1.95 \\
\hline $\mathbf{Z n}$ & $\mathbf{6 . 9 2} \pm 0.25$ & 5.99 & 125.95 & 373.1 \\
\hline $\mathbf{N i}$ & $\mathbf{1 . 3 2} \pm 0.04$ & 1.25 & No Data & No Data \\
\hline $\mathbf{A s}$ & $\mathbf{3 . 6 5} \pm 0.11$ & No Data & No Data & No Data \\
\hline $\mathbf{H g}$ & $\mathbf{n . d}$ & No Data & No Data & No Data \\
\hline
\end{tabular}

${ }^{a}$ the results obtained from present study n.d. Not Detected $<0.02 \mathrm{ng} / \mathrm{kg}$

\section{Conclusion}

This study presents new information about the distribution of trace toxic minerals in sea lettuce from the old city coastal area of Istanbul (Cankurtaran). According to the results of the current study, there is no risk for health in the consumption and evaluation of this species. However, if the consumption and evaluation of this product is considered in the future, it is recommended that the water environment of the Black Sea, Marmara and Aegean Sea coastal production / harvest potentials must be monitored periodically. 


\section{Compliance with Ethical Standard}

Conflict of interests: The authors declare that for this article they have no actual, potential or perceived conflict of interests.

\section{References}

AquaMaps (2016a). Computer generated distribution maps for Ulva lactuca (Sea lettuce), with modelled year 2100 native range map based on IPCC A2 emissions scenario. www.aquamaps.org, version of Aug. 2016. https://www.aquamaps.org/imagethumb/file destination/pic_SLB-143238.jpg and https://www.sealifebase.ca/summary/Ulva-lactuca.html (accessed 24.03.2019)

AquaMaps (2016b). Computer generated distribution maps for Ulva rigida, with modelled year 2100 native range map based on IPCC A2 emissions scenario. www.aquamaps.org, version of Aug. 2016. Web. Accessed 5 May 2019 from https://www.aquamaps.org/imagethumb/file_destination/pic_SLB-143769.jpg and https://www.sealifebase.ca/summary/Ulva-rigida.html (accessed 05.05.2019)

Belitz, H. D., Grosch, W., Schieberle, P. (2009). Food chemistry. Food Chemistry (4th ed.). Berlin Heidelberg: Springer-Verlag. https://doi.org/10.1007/978-3-540-69934-7

Culha, S.T., Kocbas, F., Gundogdu, A., Culha, M. (2013). Heavy metal levels in marine algae from Marmara Sea and Mediterranean Sea. In Mediterranean Science Comission, 40th CIESM Congress. Marsilya.

Davis, T.A., Volesky, B., Mucci, A. (2003). A review of the biochemistry of heavy metal biosorption by brown algae. Water Research, 37, 4311-4330. https://doi.org/10.1016/S0043-1354(03)00293-8
Ergul, H.A., Ay, U., Karademir, A., Cayir, B., Topcuoglu, S., Telli, B., Terzi, M. (2010). Heavy metal concentrations in biota, sediment and sea water samples from Dil Iskelesi region. In Rapp. Comm. int. Mer Médit (p. 246). Venice.

NMKL (Nordic Committee on Food Analysis). (2007). As, $\mathrm{Cd}, \mathrm{Hg}, \mathrm{Pb}$ and other elements determination by ICPMS after pressure digestion, No:186.

Özcan, M. (2004). Mineral contents of some plants used as condiments in Turkey. Food Chemistry, 84(3), 437-440. https://doi.org/10.1016/S0308-8146(03)00263-2

Ozyigit, I.I., Uyanik, O.L., Sahin, N.R., Yalcin, I.E., Demir, G. (2017). Monitoring the pollution level in Istanbul coast of the sea of Marmara using algal species Ulva lactuca L. Polish Journal of Environmental Studies, 26(2), 773-778.

https://doi.org/10.15244/pjoes/66177

Soylak, M., Saraçoğlu, S., Tüzen, M., \& Mendil, D. (2005). Determination of trace metals in mushroom samples from Kayseri, Turkey. Food Chemistry, 92(4), 649-652. https://doi.org/10.1016/j.foodchem.2004.08.032

Tchounwou, Paul B., Yedjou, Clement G., Patlolla, Anita K., Sutton, D.J. (2012). Molecular, Clinical and Environmental Toxicology. National Institures of Health Public Access, 101(August), 133-164. https://doi.org/10.1007/978-3-7643-8338-1

Topcuoğlu, S., Kılıç, Ö., Belivermiş, M. (2010). Use of marine algae as biological indicator of heavy metal pollution in Turkish marine environment. Journal of the Black Sea/Mediterranean Environment, 16(1), 43-52.

Villares, R., Puente, X., Carballeira, A. (2010). Ulva and Enteromorpha as Indicators of Heavy Metal Pollution. Hydrobiologia, 462, 221-232. https://doi.org/10.1023/A:1013154821531 